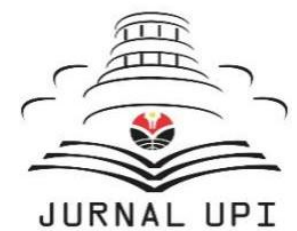

THE JOURNAL GASTRONOMY TOURISM

Volume 8 Issue 2, December 2021, 57-64

Available online at:

https://ejournal.upi.edu/index.php/gastur

\title{
Gastronomic Tourism Travel Routes Based On Android Applications In Ternate City
}

\author{
Dewi Turgarini $^{1 *}$, Heni Pridia ${ }^{2}$, Lioe Lyly Soemantri ${ }^{3}$ \\ ${ }^{1}$ Universitas Pendidikan Indonesia, Bandung 40154, West Java, Indonesia \\ ${ }^{2}$ Institut STIAMI, Jakarta 10530, West Java, Indonesia \\ ${ }^{3}$ Politeknik Sahid. Jakarta 15418, West Java, Indonesia
}

*Corresponding Author. E-mail:dewiturgarini@upi.edu (Dewi Turgarini)

\begin{abstract}
The rapid development of information technology systems in the world has forced Indonesia to immediately improve its gastronomic tourism information technology system that is easily accessible by tourists. The city of Ternate is unique both in terms of traditional/local food, history, tradition, philosophy, way of eating, way of serving, and educational value. In addition, the city also provide experiences by enjoying nutritious dishes and having good ethics. The method used is descriptive qualitative, through depth interviews, surveys and FGD analysis of the gastronomic component in Ternate City. After that, the second stage was carried out, namely designing an information system in the form of an Android application. This application provides a variety of attractions, accessibility, amenities, and additional services with a menu display that is easy for tourists to use when visiting gastronomic tourist destinations in Ternate City, then spatial mapping is carried out by tagging coordinates so that travel routes can be made. The result of the research is that valid data regarding gastronomic potential data is obtained, and an Android application is made, then an alternative gastronomic travel route is given which is expected to make it easier for special interest tourists to enjoy gastronomic tourist destinations in the city of Ternate. Further research needs to be done in the future so that tourists can extend their stay while enjoying their gastronomic trip in Ternate City.
\end{abstract}

Keywords: Information System; Gastronomy; Android Application; Tourism Route

$\begin{array}{ccc}\text { First Received: } & \text { Revised: } & \text { Accepted: } \\ \text { August 2021 } & \text { August 2021 } & \text { September 2021 }\end{array}$

Final Proof Received: November 2021
Published:

December 2021 


\section{Introduction}

The history of gastronomic development in the world is influenced by the spices obtained in the city of Ternate. This city is the one of the internationally famous waterfront cities, that can be proven by the discovery of various relics of the Portuguese fortress when allied with the Ternate Kingdom in 1512. Strong historical strength is a researcher consideration to carry out a research in this city. In addition, we can see ing the development of Gastronomic Creative Cities in the world since 2003 which was initiated by UNESCO, gastronomic in Indonesia should be immediately implement a gastronomic city development strategy, especially in the city of Ternate.

Since Indonesia was hit by the Covid-19 pandemic, it is time for the Indonesia to make efforts to develop gastronomy as one of the right strategies to do because culinary as a gastronomic tourism has good benefits in increasing the body's immunity. Based on statistics conducted by the Ministry of Tourism of the Republic of Indonesia in October 2021, Indonesia remains a tourist destination that has opportunities that can be developed. Although the data on foreign tourist arrivals to Indonesia through all entrances in September 2021 totaled 126,513 visits or decreased by $-15.08 \%$ compared to September 2020 which amounted to 148,984 visits. The international travelers come from Timor Leste, Malaysia, China, Papua New Guinea, United States of America, Yemen, United Arab Emirates, Hong Kong by $81.63 \%$, and Germany. Their entrance is through Ngurah Rai airport, Soekarno-Hatta, Batam. Although there has been a decline in arrivals, this is indeed being experienced worldwide. Therefore, the pandemic period is the right time for stakeholders in Ternate City to consolidate and develop their gastronomic tourism
Table 1. Monthly Foreign Tourism Visit

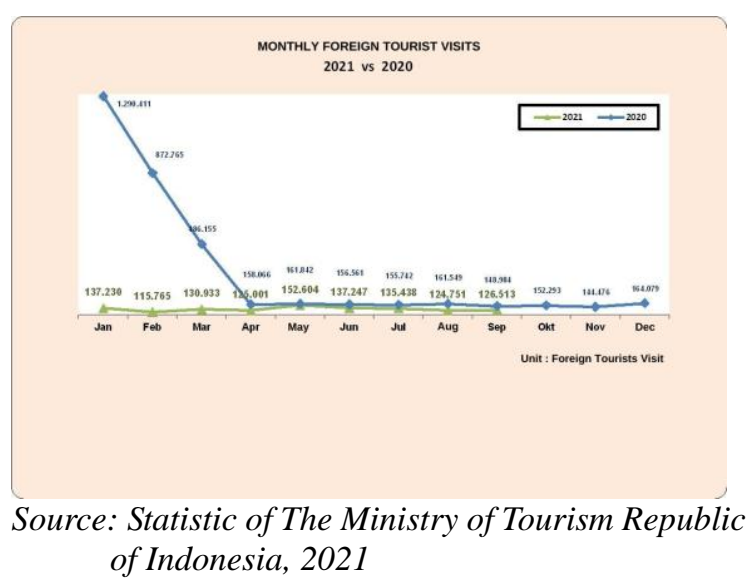

The next challenge is the unavailability of processing and using data on gastronomic attractiveness for tourism development in Ternate City. There is no information system using android application that contains data on gastronomic tourist attractions as an entry point for information sources that can be accessed by domestic and foreign tourists. Lastly is the route of gastronomic travel using a smartphone, which is indeed a means of accessing gastronomic tourist attractions efficiently and accurately.

Based on these challenges, the research team processed the database of gastronomic tourist attractions, then carried out spatial mapping and carried out coordinate tagging. The next stage is inputting the data into the android application and giving the recommended gastronomic tourism route so that it can be easily accessed by domestic and foreign tourists to make decisions to come visit and carry out gastronomic tourism activities in Ternate City.

\section{Literature Review}

Turgarini (2018) stated that food as a cultural product was an "elementary product" as a consumption means to fulfil human's basic needs to survive. However, the function of food was then transformed as "existence product" commercially and transactional, even though the food is still 
the same as the previous product. On the third step, food product benefit is now polished and enriched with art, special skill and technique through processing, cooking and then presenting it so that resulting "palate or taste product" where taste, aroma, display begin to be important to raise consumers' appetite and also healthy. The next step, food is like a fulfilment of nutrition standard, quality of life, social, experience, status, conservation to national defence. In the top, food is enriched and positioned as "gastronomy product" which can become attraction due to comprises elementary function, benefit, joyful, happiness, curiosity fulfilment, as well as social aspects. Therefore, culinary process still becomes a part of each gastronomic culture stage. Cooking itself is a food processing process from level one to five on gastronomy product. However, culinary area is only around kitchen. This is different from gastronomy which adopts all food ecosystem starts from foodshed to foodscape and dining tables even post enjoying the served dishes.

Turgarini 2018 stated that gastronomy is not merely culinary in the kitchen but also relates to the ins and outs of cultures, especially human behaviour in selecting raw material, and then in tasting, feeling, serving the food and having consuming experience, as well as in seeking, learning, researching and writing about food and everything relates to ethics, etiquette and nutrition for people in different countries (Figure 2).

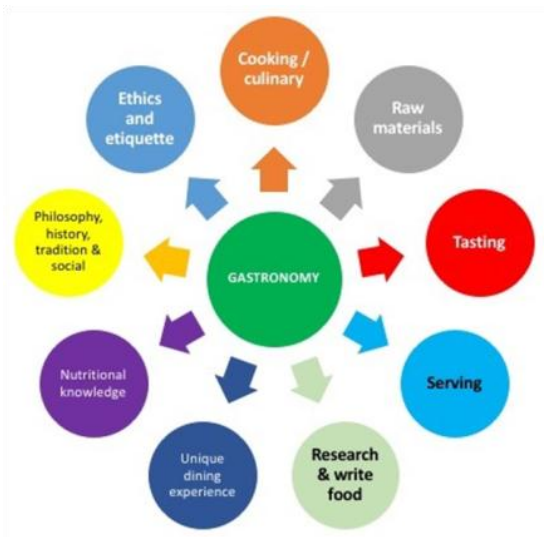

Figure 1. Component of Gastronomy Sources: Turgarini (2018)
In relation to tourism, the International Culinary Tourism Association defines gastronomy as "the pursuit of unique and memorable eating and drinking experiences" (Manolis, 2010). Chaney and Ryan (2012) identify that gastronomic tourism is one of tourism activities newly known by public. Thus, the gastronomy tourists are those who are willing to travel other places for tasting and seeking experiences over authentic local food in destinations (Pullphothong \& Sopha, 2013 in Turgarini 2018).

Information technology is an important thing that needs to be designed for the development of gastronomic tourism. This can be seen from the creativepreuneurship model of Nona Helix Dewi Turgarini (2020), where there are nine stakeholders who must work together, namely business actors, government, workers, supplier, expert, observers, connosiour, NGO's, information technology.

Information technology is an important thing that needs to be designed for the development of gastronomic tourism. This can be seen from Turgarini Nona Helix Creativepreneurship Model (2020), where there are nine stakeholders who must work together, namely business actors, government, workers, suppliers, experts, observers, consultants, NGOs, and information technology to developed gastronomic tourism.

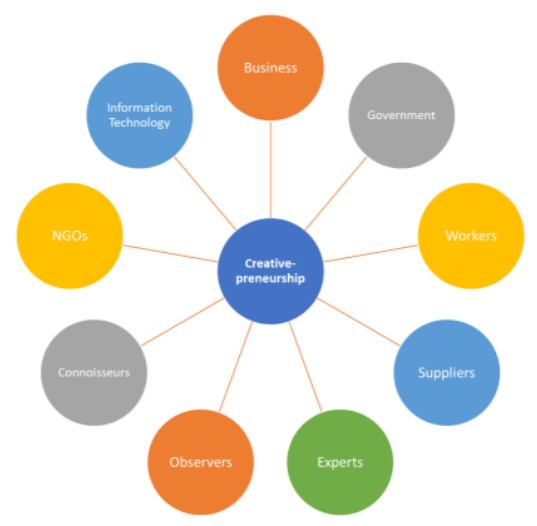

Figure 2. Nona Helix Gastronomy Creativepreuneurship

Source : Turgarini, 2021 
Turgarini (2020) explained that the information technology system needs to be created by combining various information and user activities. The information system designed is to prepare a set of interconnected gastronomic tourist attraction components that function to collect, process, store, and distribute information to support decision-making and supervision in tourism activities. The gastronomic tourism information system is designed to pay attention to the characteristics of tourist attractions such as attractions, accessibility, amenities, additional services. Turgarini (2019) stated that this is must be done so that the gastronomic information system can function to:

1) Improving the accessibility of existing data effectively and efficiently to users (tourists), without intermediary information systems.

2) Improving the productivity of the application development and maintenance of the gastronomic tourism system

3) Ensuring the availability of quality and skills in critically utilizing gastronomic tourism information systems.

4) Identifying the need for gastronomic information system support skills

5) Anticipate and understand the economic consequences of a gastronomic trip

6) Determine which investment will be directed to the gastronomic tourism information system

7) Develop an effective planning process for gastronomic tours.

The information system technology used is an Android application based on Linux. The design is done for touch screen mobile devices such as smartphones and tablet computers. The operating system is done with open source, and Google releases the code under the Apache license. The open source code and licensing licenses on Android allow software to be freely modified and distributed by device makers, wireless carriers and application developers.

Researchers chose Android because it has a low-cost, customizable, and lightweight operating system for high-tech devices. Android is also developed into additional applications on televisions, game consoles, digital cameras, and other electronic devices. Travelers in the world are already using Android applications created by the application developer community to use. This is because of the existence of open source code as the basis for application development projects, by adding new features for advanced users or operating Android on devices that were officially released using other operating systems. Turgarini (2019) states that android is the right choice as a complete, open and free future platform, because it is complete, open, free. Applications for Android can be distributed and traded in any form especially for gastronomic tourism.

The implementation of gastronomic tourism can be understood easily if spatial mapping is carried out, according to Turgarini, et al. (2019) where gastronomic tourist attractions are grouped which includes a collection of areas related to several geographical locations including highlands, mountains, resources and potentials, residents who have an impact on socio-cultural, especially gastronomic tourism which has special characteristics and uses the right scale. Technically, the data creation process is carried out, followed by data processing, and presentation in the form of maps. Maps must be easy to read, interpret and analyze by map users. The user must be able to read the map and get a real picture of the information in the field.

Maps can be useful for the development of gastronomic tourism, if a travel route is made. According to Hajiman, Caria and Turgarini (2021), the gastronomic route can involve interactions between object and intangible components such as facilities, 
services, environment, and local communities. The interaction that is built will lead to perceptions, interests, motivation and satisfaction of tourists. The preparation of a tourist route or route needs to involve 9 (nine) stakeholders (nona helix) so that this gastronomic route based on local attractions can become a brand identity or things that are unique to the area and make it different from the gastronomic tourist attraction in other areas.

\section{Materials and Methods}

The object of research is in Ternate City. This is a follow-up study that was carried out in 2016 on the potential for culinary tourism in Ternate City, which was carried out by the database team of the Culinary Tourism and Spa Division, Assistant Deputy for Cultural Tourism Development, Ministry of Tourism of the Republic of Indonesia. The study was conducted from May to November 2021. The respondents were 100 stakeholders of gastronomic tourism in Ternate City.

The stages of data collection were carried out through deep interviews, surveys and focus group discussions. Then the data is analyzed and described and designed in a digital information system in the form of an Android application by the researchers.

Data processing is carried out by analyzing data on tourist attraction descriptions, gastronomic components, and tagging the location data (GPS). Furthermore, the application is designed by identifying features, positioning in Google maps, using interfaces, and location based services. After the last phase was carried out, namely testing the application in the form of a thematically arranged map by displaying all the gastronomic data inventory of Ternate as an identified tourist attraction with the support of attachments in the form of photos and a-brief descriptions. Then as the final result of this research, the right of gastronomic travel route is analyzed which can be recommended to users.

\section{Results and Discussion}

Through research on appropriate information technology systems, tourists are expected to be able to access gastronomic tourism information systems before and during their activities. Based on the research, it is found that changes in tourist consumption patterns are due to advances in information technology, the design of this information system is indeed needed to be mapped. Through this research, it is hoped that advances in information technology can affect consumption patterns, but also have an impact on gastronomic business processes. The development of new business models in the field of gastronomy provides job opportunities and new skills. Advances in information technology in the 4.0 era can also be further utilized in the gastronomic tourism chain.

Based on the results of the data analysis of previous research, depth interviews were conducted by means of online focus group discussions, then a survey was conducted. Culinary data in Ternate City obtained are:

1) Main Course, namely: 1)Agi, 2) Ayam Bakar, 3) Boboto, 4) Beras Pupulak, 5) Batata Kukus, 6) Gatang (Walnut Crab) Kenari, 7) Fufu Fish , 8) Grilled Colo-Colo Fish, 9) Rica Fish, 10) Woku Fish , 11) Grilled Fish Bobara Fish, 12) Ikan Kuah Asam Pedis, 13) Grilled Garupa Fish, 14) Grilled Snapper Fish, 15) Asar Fish, 16) Soru Fish Soup, 17) Yellow Snapper Fish Soup, 18) Raw Snapper Dabu-Dabu Fish, 19) Fried Anchovy Fish, 20) Tore/Roa Fish, 21) Gohu Fish, 22) Ngafi Fish, 23) Garampati/Abon Fish, 24) Galema, 25) Kasbi 26) Kobo (Buffalo Ketupat), 27) Nanasi (Pineapple Ketupat), 28) Jaha Rice, 29) Papeda, 30) Grill Sagu, 31) Sagu Pupeda, 32) Soru, 33) Sarondeh, 34) Steamed Pulo , 35) Whole Chicken Semur, 36) Sour Pedis Fish Soup, 37) Sour Pedis Chicken Soup, 38) Sour Pedis Beef Soup, 39) Namo-Namo, 40) Doga Rice, 41) Cabu Bone Fish, 42) 
Yellow Rice Dada.

2) Complete Menu, namely: 1) Nasi Kuning Ikang Telur, 2) Lontong Sayur

3) Side Dish, namely: 1) Sayur Garo, 2) Sayur Lilin, 3) Fofoki (Eggplant) Kuah, 4) Gudangan, 5) Kusi, 6) Ulak-Ulak, 7) Rujak Sour Vegetable, 9) Sayur Kangkung, 10) Sayur Paku, 11) Ganemo, 12) Popare Isi Ikan 13) Ubi Pisang, 14) Ubi Talas

4) Sauce, namely: 1) Walnut Sauce, 2) Fried Suce Acar, 3) Bakasang Sauce, 4) Roa/ Tore Sauce, 5) Dabu-Dabu Sauce, 6) Dried Sauce Kasbi, 7) Tahi Minyak Sauce, 8) Anchovy Sauce

5) Dessert And Snack, namely: 1)Abud, 2) Apang, 3)Apang, Polote, 4)Amu Goreng, 5) Amo/Fried Sukun, 6) Angka Durian,7) Angka Kenari, 8)Aneka Krepek, 9)Taro Batata, 10)Bagea Kenari, 11) Balapis 7 Warna, 12) Mung Bean Porridge (Gule-Gule Tamelo), 13) Cara Isi, 14) Cucur, 15) Coe, 16) Nagasari, 17) Cocoles, 18) Emping Biji, Durian, 19) Halua, 20) Sagu Pastry, 21) Kalombeng, 22) Milu Jagung, 23) Lapis Chocolate, 24) Makron, 25) Pumpkin Coe, 26) Lamet, 27) Lapis Bendera Flag, 28)Lalampa, 29) Onde-Onde (Kelepon), 30)Pisang Goreng/Rebusmulu Bebe, 31) Pupaco, 32) Palita, 33) Walnut Bread, 34) Roti Seka Kenari, 35) Sambiki Panggang, 36) Sarikaya, 37) Sagu Loyang, 38) Sugong, 39) Surabi Cinkarong, 40) Talam Sagu, 41) Miluwok,42)Panakuk/Lenggan-Lengg an, 43) Wajik, 44) Pisang Lumpur

6) Beverage, namely: 1) Guraka Water, 2) Pala Syrup, 3) Ternate Coffee, 4) Teh Kayu Manis, 5) Guraka Coffee

The data obtained is then analyzed for its gastronomic components, then reprocessed into features which are then continued by making an overview or design of the system design that will be built into an application, starting by displaying the opening page or splash screen, then heading to the home menu containing images and feature options in Ternate City. . Furthermore, the user (tourist) can choose one of the thumbnails in the form of a feature, information related to that feature will appear, namely the main menu display, and the application main menu display, namely About Us, Food, Restaurant, Activity, News, Education \& Research, City , Thumbnail selection of Indonesian and English (Pridia, Soemarni, Turgarini, 2021).

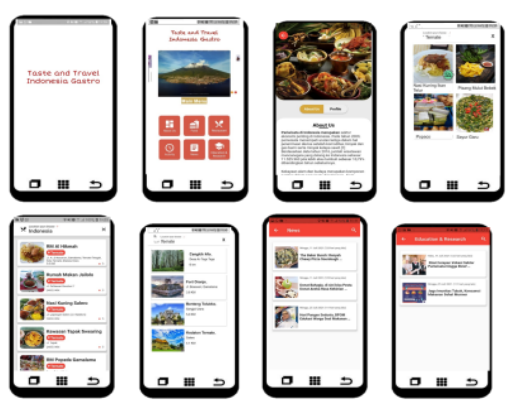

Figure 3. Ternate City Gastronomic Tourism Android Application Display Menu

Source : Pridia, Lyly, and Turgarini, 2021

The display of this Android-based gastronomic tourism application is also designed to provide convenience for tourists in finding routes to the destination tourist attraction. In addition, from a visual perspective, the application built has an attractive design with image visualization and is user friendly so that it is easily understood by tourists. The research carried out is felt to be not optimal, therefore the researchers also include alternative travel patterns that can be an option for tourists to become their activities during a gastronomic tour in the city of Ternate, which are as follows: 


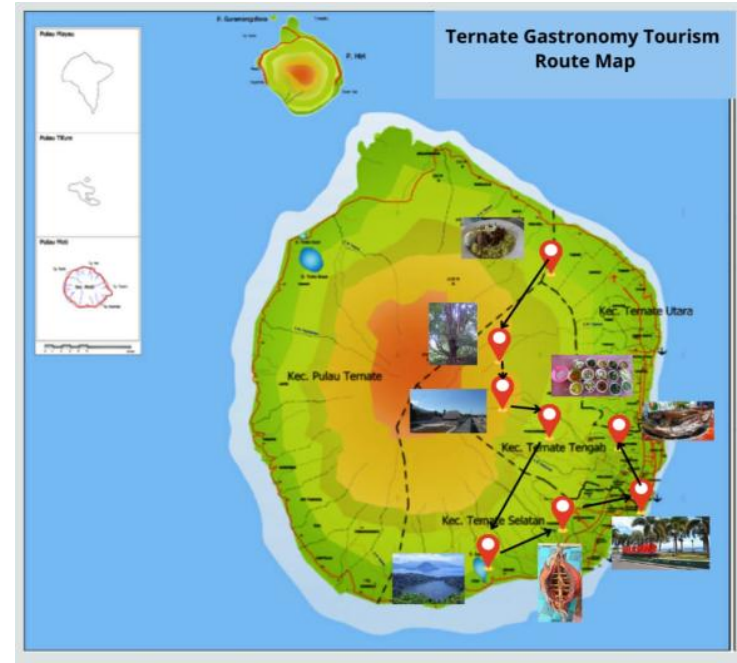

Figure 4. Gastronomic Tourism Route in Gastronomy City

Source : Processed by Dewi Turgarini, 2021

\section{Conclusions}

Based on the results of these studies, it is concluded that the design can be applied in the application of gastronomic tourism in Ternate City. The main features featured in this gastronomic travel app are authentic food, places to eat/restaurants, and activities. Each feature is made comprehensive so that users will get complete information when going on a gastronomic tour. In addition to the main features, the application is also equipped with complementary data such as 'News' and 'Education \& Research'. Mapping of information that will be available to provide comprehensive educational value for the development of gastronomic tourism in Ternate City. The display of this Android-based gastronomic tourism application is also designed to provide convenience for tourists in finding routes to the destination tourist attraction.

In addition, from a visual perspective, the application built has an attractive design with image visualization and is user friendly so that it is easily understood by tourists. There are drawbacks for interested users. It is recommended for further research with the same object and the same criteria, and can be developed again into a more multipurpose application.

For optimal research, it is necessary to update data on an ongoing basis so that tourists get the latest data (real time). This android application-based gastronomic travel route needs to be socialized and provide benefits to potential users who will become tourists of special interest in gastronomic tourism in Ternate City. Of course in the future further research needs to be done in order to maximize this application comprehensively for tourism development in Ternate City.

\section{Acknowledgment}

This research is the result of the collaborative from researchers at the Catering Industry Management Study Program, and Hospitality \& Tourism Study Program, STIAMI Institute, also Travel Business Study Program, Sahid Polytechnic. There is also participant from the expert of information technology, and tourism practitioners in the City of Ternate. Thank you to all stakeholders who contributed to the implementation of research activities that ran for 6 months.

\section{References}

Division Culinary and Spa Deputy. (2015). Database Culinary Tourism in 1915 Assistance of Tourism Culture. Jakarta.

Heru A Umanailo, et all. (2017). Perkembangan Pusat Kota Ternate (Studi Kasus : Kecamatan Ternate Tengah).

https://ejournal.unsrat.ac.id/index.php /spasial/article/view/18268. Accesed 6 December 2021. Accesed 6 December 2021.

Hajiman, Ningsih, Turgarini. 2021. Persepsi Wisatawan Terhadap Tradisi Makan Bedulang Sebagai Wisata Gastronomi Di Belitung Timur. Jurnal Industri Pariwisata. Vol.4, No.1. Tahun 2021.

Ministry of Tourism Republic Indonesia. 2021. Statistik Wisatawan Mancanegara.

https://kemenparekraf.go.id/statistikwisatawan-mancanegara/Statistik-Ku 
njungan-Wisatawan-Mancanegara-20 21. Accesed 6 December 2021.

Turgarini, Pridia. 2016. Gastronomy Tourism Attraction in Ternate City. https://www.atlantis-press.com/proce edings/ictgtd-16/25868923. Accesed 7 December 2021.

Turgarini. (2018). Gastronomy Sunda as Tourist Attraction in Bandung City. Yogyakarta. University of Gadjah Mada.

Turgarini. (2019). Bandung City as a Sundanese Gastronomy Foodscape. Digital Press Social Sciences and Humanities. Proceeting of Indonesia Heritage Tourism Fourum 2019.

Turgarini. (2021). The Salapan Cinyusu (Nona Helix as a "creativepreuneurship" Support Model for Gastronomy Tourism in Bandung City. Promoting Creative Tourism : Current Issues in Tourism Research. Taylor \& Francis Group, London. ISBN 978-0-367-55862-8.

Turgarini, et.al. (2019). Android Application as Information System of Sunda Gastronomic for Tourism Attraction in Bandung City. https://www.scitepress.org/Papers/20 19/97856/pdf/index.html. Accesed 6 December 2021

Pridia, Soemarni, Turgarini. 2021. Strategi Penggunaan Aplikasi Android dalam Meningkatkan Sistem Informasi Wisata Gastronomi Kota Ternate. Jakarta. STIAMI 